Association for Information Systems

AIS Electronic Library (AISeL)

ECIS 2000 Proceedings

European Conference on Information Systems

(ECIS)

2000

\title{
Developing a Relevant Research Agenda in Knowledge Management - Bridging the Gap Between Knowing and Doing
}

Edward Truch

Henley Management College

Jean-Noel Ezingeard

Henley Management Colleg

David W. Birchall

Henley Management College

Follow this and additional works at: http://aisel.aisnet.org/ecis2000

\section{Recommended Citation}

Truch, Edward; Ezingeard, Jean-Noel; and Birchall, David W., "Developing a Relevant Research Agenda in Knowledge Management Bridging the Gap Between Knowing and Doing" (2000). ECIS 2000 Proceedings. 186.

http://aisel.aisnet.org/ecis2000/186

This material is brought to you by the European Conference on Information Systems (ECIS) at AIS Electronic Library (AISeL). It has been accepted for inclusion in ECIS 2000 Proceedings by an authorized administrator of AIS Electronic Library (AISeL). For more information, please contact elibrary@aisnet.org. 


\title{
Developing a relevant research agenda in Knowledge Management - bridging the gap between knowing and doing
}

\author{
Edward Truch, J ean-Noel Ezingeard, David W.Birchall \\ Henley Management College \\ Greenlands, Henley -on-Thames \\ Oxon RG9 3AU, UK
}

\begin{abstract}
A study of research needs in knowledge management involving a cross-section of business practitioners, consultants and academics. The findings indicate a need for more interactive research.
\end{abstract}

\section{Introduction}

At last year's ECIS conference, Swan et al. [1] demonstrated how the academic community's interest in Knowledge Management (KM) has grown substantially since the mid-90s. The measure used by Swan et al. was the number of references to Knowledge Management in bibliographical databases. $\mathrm{KM}$ is a puzzling research area for many academics. There is a growing body of opinion that suggests that KM is a 'fad'. The argument used by some academics and practitioners is that there is in fact little new thinking under the umbrella of $\mathrm{KM}$, an $\mathrm{d}$ that the term is little more than a useful marketing tool in ' management fashion' [2]. We do not propose to enter into this debate, but instead to recognise that KM is a real issue for managers and, therefore, worthy of further research. Indeed, academic interest in the subject shows no sign of fading, and many companies find that they actually derive significant benefits from Knowledge Management.

The development in strategic management of the ' resource-based' view of the firm [3] has been extended to a 'knowledge-based' theory of the firm [4]. However, it has been argued that this resource -based approach has not yet reached the stage of building a comprehensive theoretical framework [5]. The incorporation of ' invisible assets' [6], and the explicit attention to core competence s of an organisation [7] or capabilities-based competition [8] offer substantial potential for f uture research. Other authors [4] have taken more of a process -oriented view of KM. Both approaches have been conidered in reviewing the results of this study.

In this paper the authors report the outcomes of an exercise aimed at developing a research agend a for Knowledge Management. The work is based on both an overview of literature to position contributions to the field and interactive sessions with business executives, researchers and consultants actively engaged in the field.

The authors propose that such an agenda should ideally be comprised of four elements i.e. primarily the themes, the nature of the deliverables, the strategy for dissemination and the research process. The work was undertaken within the context of an investigation of the fe asibility of establishing a Centre for Knowledge Management to be based within a business school. The article concludes with reflections on the overall process adopted. The main contribution of the paper is to increase the understanding of the areas of Knowledge Management of concern to three distinct communities: academics, consultants and practitioners through the analysis of a rich set of data grounded in a framework derived from the literature.

\section{Background}

The context of the work presented here is the development of a Knowledge Management research agenda in a partnership process between the end users of the research (business) and the providers (academics). This approach relies on engaging a significant cross section of interested parties. A strong proponent of this approach is Henley Management College which was founded in the $1940 \mathrm{~s}$ to develop general management expertise. It was not until the 1970' s that it developed postgraduate study leading to formal qualifications. As a result it has considerable ex perience of working closely with both business and not-for-profit organisations in the development of managerial competence. It has a long standing tradition of working in collaboration with corporate clients to tailor development activities to meet specific organisational needs. Thus overall there is considerable experience at Henley of adopting a partnership model with busi ness for research and dissemination as well as demonstrable success. The authors feel that this partnership approach is necessary in an emerging field like Knowledge Management where the exact nature of the needs of business is poorly understood by practitioners and academics alike. The initiative which forms the basis of this research was therefore intended to provide a focus for the growing interest amongst faculty members and researchers in the field of Knowledge Management. Following initial discussion with several companies heavily committed to KM projects, the College took the initiative in designing and offering a one day conference aimed at a group of practitioners in the field. The conference formed part of an initiative by the Ce ntre for Technology Management at Cambridge University, under sponsorship from the UK's Engineering and Physical Sciences Research Council (EPSRC), to test a networking concept. It took place in October 1999. 
In line with the partnership philosophy of the College, the authors in designing the conference sought to achieve a blending of both academic and practitioner thinking. As a result the morning comprised a talk by a business strategy professor giving a broad introduction to the area from a strategy perspective within the context of globalising business. Two other presentations focused on practice; one from the perspective of a global pharmaceuticals company, the other from a 'Big Five' consulting company. In all sessions issues were raised but not with the deliberate intention of shaping the research agenda.

In a separate session, the authors gave a brief introduction to the centre and asked delegates to complete a short questionnaire. This was followed by s everal focus group meetings, one of which aimed to identify specific research needs. This information forms the basis of the results presented here.

\section{Methodology}

The principal methods for data collection were an open ended questionnaire survey of participants at a conference and a focus group made up of conference attendees. In addition general searches and overviews of the literature have supplemented the investigatory work undertaken at the conference. These are not intended to be comprehensive but rather indicative. This was carried out to establish the types of contributions coming from the range of disciplines. The resulting framework was used to analyse the data gathered at the conference. This followed the analysis of the data and was undertaken in what appeared to be a key area of need so as to establish gaps between the outcomes of this investigation and research reported elsewhere.

Of particular relevance to this analysis were 5 questions in the survey questionnaire:
- Job title

- Organisation by which employed

- Level of interest in participating in the proposed Centre (with one of four response boxes to be completed)

- Key issues that the Centre should address - an open-ended question

- Benefits that membership of the Centre would bring-also an open-ended question.

These questions were intended to enable the founders of the centre to gain a clear idea of those issues which might form the res earch agenda and how that agenda might be developed to provide outcomes of benefit to potential participants. The open-ended nature of the questions was deliberate so as to elicit the greatest possible diversity in responses.

A total of 68 participants com pleted the questionnaire. Of those respondents, 43 were from business, 16 from academic institutions and 9 from consultancy. In addition to the questionnaire, a number of focus groups were held. These lasted one hour and involved between 8 and 12 participants. One of the focus groups was specifically briefed to investigate the KM research agenda. The analysis of the results was grounded in a framework derived from a review of the literature presented below.

\section{Literature review}

A striking feature of the research and practitioner literature on Knowledge Management is that it spans a wide range of disciplines and topics. The types of question asked in the literature also vary widely, and range from scoping questions about KM to philosophical de bate about the nature and value of knowledge.

This point is illustrated in Table 1. We have attempted to classify a number of issues raised in $\mathrm{KM}$ research.

\begin{tabular}{|l|l|l|l|}
\hline & Justification (why) & Implementation (how) & Scoping (what) \\
\hline Philosophy & & $\begin{array}{l}\text { Knowledge creation [9] } \\
\text { and conversion [10] }\end{array}$ & $\begin{array}{l}\text { Nature of Knowledge [3] } \\
\text { Hierarchy of Knowledge } \\
{[12]}\end{array}$ \\
\hline Economics & $\begin{array}{l}\text { Valuing knowledge assets } \\
{[26]}\end{array}$ & $\begin{array}{l}\text { Getting Value from } \\
\text { Knowledge Assets [4] }\end{array}$ & $\begin{array}{l}\text { The Knowledge Economy } \\
{[5]} \\
\text { Cross national } \\
\text { comparisons [6] }\end{array}$ \\
\hline Strategic Management & $\begin{array}{l}\text { Knowledge-based theory } \\
\text { of the firm [4] } \\
\text { Competitive advantage } \\
\text { from KM [7] }\end{array}$ & $\begin{array}{l}\text { Knowledge strategy [8] } \\
\text { Road-mapping tools [9] } \\
\text { Taxonomy of knowledge } \\
\text { strategies [19] }\end{array}$ & $\begin{array}{l}\text { Core competencies [7] } \\
\text { Knowledge assets [13] } \\
\text { Chief Knowledge Officer } \\
\text { Role [20] }\end{array}$ \\
\hline $\begin{array}{l}\text { Organisation Theory and } \\
\text { sociology }\end{array}$ & $\begin{array}{l}\text { Human capital [9] } \\
\text { Knowledge-based theory } \\
\text { of the firm [11] }\end{array}$ & $\begin{array}{l}\text { Learning [12] } \\
\text { Dynamic development of } \\
\text { Knowledge [13] }\end{array}$ & $\begin{array}{l}\text { Socio-technical analysis } \\
\text { [14] } \\
\text { Knowledge workers [15] }\end{array}$ \\
\hline $\begin{array}{l}\text { Functional Management } \\
\text { (IT, Marketing, HR) }\end{array}$ & Measurement tools [16] & $\begin{array}{l}\text { IT support } \\
\text { Intermediaries and } \\
\text { networks } \\
\text { KM practices [17] }\end{array}$ & $\begin{array}{l}\text { Towards KM [18] } \\
\text { KM errors [19] }\end{array}$ \\
\hline
\end{tabular}

Table 1: Knowledge Management Research Span 
Firstly we have grouped publications according to the academic discipline that we felt best represented the research. Three categories seem to emerge:

- Papers that are mainly of a philosophical nature ;

- Research that asks questions that are mainly in the sphere of economics ;

- Research that is in the general management sphere. We felt that it would be useful to split this category to include papers that were mainly concerned with :

- functional management issues; and

- strategic management issues.

Secondly, it is possible to examine the type s of question that are addresse d by published research in KM. Here we find that there are broadly three types of questions

- Scoping questions, attempting to define and position KM (the what);

- Justification questions, attempting to explore why $\mathrm{KM}$ could be of benefit (the why) ; and

- Implementation questions, investigating the best way to implement KM (the how) .

When combined, the two dimensions (discipline and type of question ) provide an interesting typology of the published research. This typology seems to indicate that in order to unders tand $\mathrm{KM}$, it is necessary to use the tools, traditions and methods of a broad array of disciplines. This is not surprising because of the collection of skills, stakeholders and technologies that are required in any KM initiative. No single discipline is likely to emerge as the natural home of Knowledge Management. The topic is therefore likely to remain an umbrella theme, bringing together subjects that are traditionally seen as far apart.

This typology was used as a framework to classify the responses obtained from the questionnaire. The responses to the open-ended question about key issues to be addressed were then grouped into 8 categories (table 2) according to the underpinning discipline. We have included psychology as a separate discipline as some answers lent themselves to this heading. We also added a fourth category to the stages in the development process emerging from the overview of the literature, evaluation (the result), as this emerged as one of the stages some of the respondents were int erested in.

\section{Results}

The results of the thematic classification are shown in Table 2. Two types of question dominate - scoping and implementation. Also, Operations Management is the discipline into which most questions wer e categorised. Fewer questions raised fall into the more traditional academic disciplines of philosophy, psychology and sociology/organisation behaviour. This is perhaps not too surprising as one would really expect a predominantly practitioner audience to be more concerned about questions of implementation rather than more fundamental understanding, concept definition and elaboration. The more fundamental questions dealt with topics such as:

- Defining the nature of Knowledge

- Valuing Knowledge and Knowle dge Management initiatives

- Measuring the organisational impact of Knowledge Management

- Organisation models and Knowledge Management

- Structure, culture and change

- Motivation and the nature of tacit knowledge.

Following on from this exercise, the respons es to the open-ended questions were further categorised by theme and grouped as follows:

- Key issues. Here, 8 themes emerged (Strategic perspectives; Measurement; Implementation issues; Tools and techniques; Models; Best practice; Research topics; Practica 1 issues)

- Benefits of membership. Here 13 areas emerged, which we grouped under 4 headings :

1. Business benefits (Performance; Purchasing benefits; Consultancy; Benchmarking; Training).

2. Knowledge of Knowledge Management (Information; Research outputs/leading edge thinking; Tools and techniques; Cases)

3. Sharing (Meetings; Exchange mechanisms; Joint development)

4. Access for personal learning

\begin{tabular}{|l|c|c|c|c|c|c|}
\hline Discipline & Justification & Scoping & Implementation & Evaluation & Total & $\%$ \\
\hline Economics & 3 & 3 & 1 & 2 & 9 & 10.3 \\
\hline Philosophy & 0 & 5 & 0 & 0 & 5 & 5.7 \\
\hline Psychology & 0 & 2 & 5 & 0 & 7 & 8.0 \\
\hline Sociology/ Organisation Theory & 0 & 3 & 3 & 2 & 8 & 9.2 \\
\hline Strategic Management & 4 & 9 & 4 & 0 & 17 & 19.5 \\
\hline Operations Management & 2 & 8 & 4 & 6 & 20 & 23.0 \\
\hline Operations - IT & 0 & 6 & 5 & 0 & 11 & 12.6 \\
\hline Operations - HR & 1 & 1 & 7 & 2 & 11 & 11.5 \\
\hline Total & 10 & 37 & 29 & 12 & 88 & \\
\hline
\end{tabular}

Table 2: Topics categorised by discipline and type of research question 


\begin{tabular}{|c|c|c|c|c|c|c|c|c|}
\hline & Total & $\%$ & $\begin{array}{r}\text { Respondents } \\
\text { from } \\
\text { business } \\
\end{array}$ & $\%$ & $\begin{array}{r}\text { Respondents } \\
\text { from } \\
\text { academia } \\
\end{array}$ & $\%$ & $\begin{array}{r}\text { Respondents } \\
\text { from } \\
\text { consultancy }\end{array}$ & $\%$ \\
\hline Strategic perspecti ves & 16 & 11.5 & 11 & 12.6 & 3 & 9.1 & 2 & 10.5 \\
\hline Measurement & 19 & 13.7 & 14 & 16.1 & 3 & 9.1 & 2 & 10.5 \\
\hline Implementation issues & 28 & 20.1 & 19 & 21.8 & 4 & 12.1 & 5 & 26.3 \\
\hline Tools \& Techniques & 8 & 5.7 & 6 & 6.9 & 0 & 0 & 2 & 10.5 \\
\hline Models & 12 & 8.6 & 9 & 10.3 & 2 & 6.1 & 1 & 5.3 \\
\hline Best practice & 16 & 11.5 & 11 & 12.6 & 2 & 6.1 & 3 & 15.8 \\
\hline Research topics & 19 & 13.7 & 4 & 4.6 & 13 & 39.4 & 2 & 10.5 \\
\hline Practical issues & 21 & 15.1 & 13 & 14.9 & 6 & 18.2 & 2 & 10.5 \\
\hline Total & 139 & & 87 & & 33 & & 19 & \\
\hline
\end{tabular}

Table 3: The number of responses falling into thematic areas

The results of this classification a re presented in table $\mathrm{s}$ 3 and 5. Table 3 shows that the highest concern was to gain more information about issues to do with 'implementation'. This was particularly the case amongst consultants. Business interest also was focused on 'measurement' . Best practice' also received a relatively high number of mentions. The academics identified most of the themes which were subsequently classified as 'research topics'. Tools and techniques' were not high on the agenda, something that was of some surprise. S o these results give us an indication of what was uppermost in the thinking of each group at the time, and points towards needs in relation to content of activities. It emerges that this group of practitioners was concerned particularly about aspects to do with making progress in moving organisations forward at an operational level possibly because strategies now need to be translated into practice.

As mentioned earlier, one of the focus group meetings concentrated its efforts on the content of a re search agenda. The participants had the benefit of having already given some thought to those themes they wanted the Centre to pursue but in this meeting they addressed specific issues of research. The results are presented in table 4. This resulted in ad ditional topics but without the weightings obtained from the earlier analysis. However this does highlight some additional issues under the three themes presented.
An interesting feature of the themes presented in table 4 is that many are linked to impl ementation issues. This reinforces our earlier conclusion that implementation is one of the areas that generates the most concern. In addition, it is interesting that, although many of the themes that emerged during the focus group are very context dependant, no-one in the group indicated that other people's concerns were irrelevant to them. This suggests that many participants are still very unsure about what the Knowledge Management agenda should look like in their organisations, and what issues they shou ld focus on.

The perceived benefits of membership of a Knowledge Management centre are shown in table 5. This analysis helps us see in what ways the outputs might be used and hence the research adopted.

By far the greatest response related to 'consultancy' with business having the highest level of response in this category. The next most heavily loaded category was 'information'. Despite the audience being expected to have experience in the area there was still a strong desire for information of a fairly ba sic nature from a Centre. Again this was particularly sought by business people. 'Research outputs and leading edge thinking' was more frequently sought by academics than by business people with consultants also wanting access to such information.

\begin{tabular}{|c|c|}
\hline $\begin{array}{l}\text { 1. User Perspectives } \\
\text { How Knowledge Management (KM) processes map onto people an } \\
\text { motivations } \\
\text { - Internal markets for knowledge; communities of practice (internal and } \\
\text { communities (retention and security issues) } \\
\text { - Knowledge workers and social exclusion; knowledge have' s and have -n } \\
\text { - Role of shared conceptual models in knowledge sharing and creation }\end{array}$ & $\begin{array}{l}\mathrm{d} \text { their interests and } \\
\text { external) and expert } \\
\text { not's }\end{array}$ \\
\hline $\begin{array}{l}\text { 2. Organisational Turbulence and Flexibility } \\
\text { - } \quad \text { Mergers and acquisitions } \\
\text { - Knowledge management and alliances } \\
\text { KM practices and organisational context; constraints on implementation }\end{array}$ & \\
\hline $\begin{array}{l}\text { 3. Balance between People, Process and Technology } \\
\text { - } \quad \text { Failure of BPR initiatives } \\
\text { - Knowledge support of processes; modelling techniques } \\
\text { - Conversion of tacit to explicit knowledge } \\
\text { - How companies gain knowledge of knowledge sources } \\
\text { - Deciding whether to outsource where knowledge as sets are concerned } \\
\text { - Capturing information and converting to knowledge } \\
\text { - Survey and audit of KM tools }\end{array}$ & \\
\hline
\end{tabular}

Table 4: Themes emerging from the 'Research Directions' Focus group meeting 
This is not surprising from consultants as they are, to some degree, in a business which thrives on transferring new ideas into business and they seek thought leadership in relation to their clients. One may see academics as having a similar need with regard to their courses. We had anticipated that there would be a particular interest in benchmarking. The business people indicated that it was an issue for them. However, these business people did not appear to see this type of Centre as offering benchmarking information. One might conclude that, if research is to be effectively disseminated, academics and consultants have a key role to play here. Unless the outcomes offer clear assistance in implementation of Knowledge Management , business will not be directly attracted to the research activity.

One aspect of the investigation to which we anticipated a response from this question was the involvement of the parties in the knowledge creation process. The level of response concerning 'joint development' was low with only 5\% of responses within that category and those mostly from academics. Given the rapid development of the field of practice, if not research, we had anticipated that the respondents would seek participation in the research approach. The interest i $\mathrm{n}$ actually participating in the research process appears not to be high amongst the business group in particular. This could be interpreted as confirmation that many practitioners see Knowledge Management as a 'technical fix', with concerns centred on implementation issues. This is somehow puzzling as it seems to indicate that there is almost a naï ve expectation that technical solutions are possible without the need for sound grounding in understanding of the Knowledge
Management process . However, it is clear that, when there are outputs from research, participants want to benefit from consultancy, information dissemination and actual direct application of research outputs.

\section{Discussion and conclusions}

We have so far highlighted three areas where significant interest seems to emerge from the data collected:

- Implementation issues

- Best practice

- Measurement

It is worth noting how these areas apply to both the theoretical stances mentioned in the introduction. Implementation and best practice lend themselve $s$ to the process-oriented view of KM, whilst measurement applies more directly to a resource -based view of the firm with knowledge seen as a valuable asset.

These areas represent a challenge for academics. In particular, implementation issues are not usua lly associated with academic research. In addition, the data seem to indicate wide differences between the expectations of industry and the interests of academics. Despite these differences, there was considerable interest in the event. There seems to be substantial uncertainty amongst managers about the meaning and impact of KM, and yet they are primarily concerned with implementation. This apparent anomaly might be the result of the fast rate of change where managers are under pressure to act before they have developed a full and detailed understanding of the situation they are dealing with.

\begin{tabular}{|l|l|c|c|c|c|c|c|c|c|}
\hline & & \multicolumn{2}{|c|}{ Overall } & \multicolumn{2}{c|}{ Consultants } & \multicolumn{2}{c|}{ Academe } & \multicolumn{2}{c|}{ Business } \\
\hline Aim & Area & Number & $\mathbf{\%}$ & Number & $\mathbf{\%}$ & Number & \% & Number & \% \\
\hline Business benefits & Performance & 3.0 & 2.0 & 0.0 & 0.0 & 0.0 & 0.0 & 3.0 & 2.8 \\
\hline & Purchasing benefits & 2.0 & 1.3 & 1.0 & 4.3 & 0.0 & 0.0 & 1.0 & 0.9 \\
\hline & Consultancy & 34.0 & 22.4 & 4.0 & 17.4 & 4.0 & 19.0 & 26.0 & 24.1 \\
\hline & Benchmarking & 11.0 & 7.2 & 1.0 & 4.3 & 0.0 & 0.0 & 10.0 & 9.3 \\
\hline & Training & 2.0 & 1.3 & 0.0 & 0.0 & 0.0 & 0.0 & 2.0 & 1.9 \\
\hline $\begin{array}{l}\text { Knowledge of } \\
\text { KM }\end{array}$ & Information & 26.0 & 17.1 & 3.0 & 13.0 & 3.0 & 14.3 & 20.0 & 18.5 \\
\hline & $\begin{array}{l}\text { Research } \\
\text { outputs/leading edge } \\
\text { thinking }\end{array}$ & 21.0 & 13.8 & 4.0 & 17.4 & 5.0 & 23.8 & 12.0 & 11.1 \\
\hline & Tools/techniques & 4.0 & 2.6 & 0.0 & 0.0 & 0.0 & 0.0 & 4.0 & 3.7 \\
\hline Sharing & Cases & 14.0 & 9.2 & 2.0 & 8.7 & 2.0 & 9.5 & 10.0 & 9.3 \\
\hline & Meetings & 14.0 & 9.2 & 2.0 & 8.7 & 2.0 & 9.5 & 10.0 & 9.3 \\
\hline & Exchange mechanisms & 10.0 & 6.6 & 2.0 & 8.7 & 0.0 & 0.0 & 8.0 & 7.4 \\
\hline $\begin{array}{l}\text { Access for } \\
\text { personal learning }\end{array}$ & Joint development & 8.0 & 5.3 & 2.0 & 8.7 & 4.0 & 19.0 & 2.0 & 1.9 \\
\hline TOTAL & & 3.0 & 2.0 & 2.0 & 8.7 & 1.0 & 4.8 & 0.0 & 0.0 \\
\hline
\end{tabular}

Table 5: The benefits sought from participation in the proposed centre 
In some ways, this is analogous to concurrent engineering where design and construction proceed simultaneously. This points towards the need to develop mechanisms that can be used to develop an understanding of the topic and its pra ctical use to business. In particular, two distinct areas where future work by academics could be very useful emerge.

Firstly, it seems that a synthesis of theories and models developed for different areas/functions of the business is needed. We have shown here that many academic disciplines have different views and different areas of interest in Knowledge Management, yet business managers are more interested in what KM means for their function, their business unit or their company as a whole. A single-discipline based approach is unlikely to be useful.

Secondly, because KM is an emerging area, there has been very little interaction between research and practice. It is, therefore, suggested that academics should take a lead in bringing these communities of interest together. This could take the form of 'interactive' research. This could overcome the lack of shared understanding about the topic as well as the fast moving nature of the topic.

The process adopted to build the research agenda presented here has tried to balance the views of the three main groups of stakeholders in the research: academics, consultants and business. In applying a grounded methodology to data collected from a wide cross section of practitioners, we have highlighted a lack of common understanding about what KM involves and this can at first sight appear surprising. We have, however, concluded that this could be bridged naturally, as the topic develops, through a research process that keeps the stakeholders closely involved at all stages.

\section{References}

1. Swan, J. and H. Scarbrough. Knowledge Management: The next fad to forget people? in 7th European Conference on Information Systems. 1998. Copenhagen.

2. Scarbrough, H. Knowledge Management and The Management Fashion Perspective. in British Academy of Management Conference. 1999. Manchester.

3. Teece, D., G. Pisano, and A. Shuen, Dynamic Capabilities and Strategic Management. Strategic Management Journal, 1997. 18(7): p. 509-533.

4. Spender, J.C., Making Knowledge the Basis of a Dynamic Theory of the Firm. Strategic Management Journal, 1996. 17(Winter Special Issue): p. 45-62.

5. Lowendahl, B. and O. Revang, Challenges to Existing Strategy Theory in a Postindustrial Society. Strategic Management Journal, 1998. 19: p. 755-773.

6. Itami, H., Mobilising Invisible Assets. 1987, Cambridge, MA: Harvard University Press.
7. Hamel, G. and C.K. Prahalad, The Core Competence of the Corporation. Harvard Business Review, 1990. 68: p. 79-91.

8. Stalk, G., P. Evans, and L. Shulman, Competing on capabilities: The new rules of corporate strategy. Harvard Business Review, 1992. 70(2): p. 57-69.

9. Nonaka, I., The Knowledge-Creating Company. Harvard Business Review, 1991. Nov-Dec 1991: p. 96-104.

10. Nonaka, I., P. Reinmoeller, and D. Senoo, The 'ART' of Knowledge: Systems to Capitalise on Market Knowledge. European Management Journal, 1998. 16(6, Dec 1998): p. 673-684.

11. Cohen, D., Towards a Knowledge Context. California Management Review, 1998. 40(3): p. 40.

12. Sanchez, R. and J.T. Mahoney, Modularity, Flexibility, and Knowledge Management in Product and Organisation Design. Strategic Management Journal, 1996. 17(Winter Special Issue): p. 63-76.

13. Teece, D.J., Capturing Value from Knowledge Assets. California Management Review, 1998. 40(3): p. 55-78.

14. Thompson, P., Technological opportunity and the growth of knowledge: A Schumpeterian approach to measurement. Journal of Evolutionary Economics, 1996. 6: p. 77-97.

15. Windrum, P. and M. Tomlinson, Knowledgeintensive services and international competitiveness: A four country comparison. Technology Analysis \& Strategic Management, 1999. 11(3): p. 391-408.

16. Hansen, M.T., N. Nohria, and T. Thierney, What's Your Strategy for Managing Knowledge. Harvard Business Review, 1999(March-April): p. 106-116.

17. Davenport, T.H., D.W. De Long, and M.C. Beers, Successful Knowledge Management Projects. Sloan Management Review, 1998. Winter: p. 43-57.

18. Zack, M.H., Developing a Knowledge Strategy. California Management Review, 1999. 41(3): p. 125145.

19. Wiig, K.M., Integrating Intellectual Capital and Knowledge Management. Long Range Planning, 1997. 30(3): p. 399-405.

20. Earl, M. and I.A. Scott, What is a Chief Knowledge Officer. Sloan Management Review, 1999. 40(2): p. 29-38.

21. Grant, R.M., A knowledge-based theory of inter-firm collaboration. Academy of Management Journal, 1995(Best Papers Proceedings 1995): p. 17-21.

22. Collinson, S., Knowledge Management Capabilities for Steel Makers: A British-Japanese Corporate Alliance for Organisational Learning. Technology Analysis and Strategic Management, 1999. 11(3): p. 337-358.

23. Nahapiet, J. and S. Ghoshal, Social Capital, Intellectual Capital and the Organisational 
Advantage. Academy of Management Review, 1998. 23(2): p. 242-166.

24. Pan, S. and H. Scarbrough, Knowledge management in practice: An exploratory case study. Technology Analysis \& Strategic Management, 1999. 11(3).

25. Scarbrough, H., Knowledge as work: Conflicts in the management of knowledge workers. Technology Analysis and Strategic Management, 1999. 11(1): p. 5-16.

26. Bontis, N., N.C. Dragonetti, K. Jacobsen, and G. Roos, The knowledge toolbox: A review of the tools available to measure and manage intangible resources. European Management Journal, 1999. 17(4).

27. Ruggles, R., The State of the Notion: Knowledge Management in Practice. California Management Review, 1998. 40(3): p. 80-89.

28. Brown, J.S. and P. Duguid, Organizing Knowledge. California Management Review, 1998. 40(3): p. 90111.

29. Fahey, L. and L. Prusak, The Eleven Deadliest Sins of Knowledge Management. California Management Review, 1998. 40(3): p. 265-276. 